\title{
Management of the palm Astrocaryum chambira Burret (Arecaceae) in northwest Amazon
}

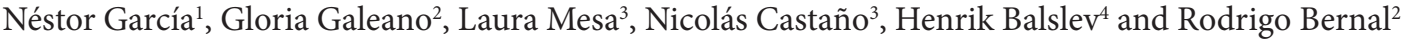

Received: December 04, 2013. Accepted: September 1, 2014

\begin{abstract}
We studied the management of the fiber-producing chambira palm Astrocaryum chambira by indigenous people in the Colombian Amazon. Between 2009 and 2012, we visited four communities and two marketing centers, where we interviewed 12 people. In addition, we specifically observed $A$. chambira harvesting, processing, and commercialization; studied palm populations at five localities; measured leaf production rate; and integrated secondary data. At least 21 aboriginal groups in the Colombian Amazon use chambira fiber. The palm grows in association with human communities, and it has been widely used and managed in past agroforestry systems. The fiber is obtained from the unexpanded leaves of juvenile or adult palms, and harvesting is often unsustainable because of overharvesting acaulescent palms or of cutting down adult palms. This is leading to a depletion of palm population. Annual leaf production rate was 1.59-2.89 leaves/palm year ${ }^{-1}$, which is lower than that reported in other studies. Based in our results, we recommended a harvest of 1 leaf/palm year ${ }^{-1}$ in acaulescent palms, and 1-2 leaves/palm year ${ }^{-1}$ in stemmed palms. Chambira-derived products are mostly handicrafts for marketing, and their trade represents $40 \%-100 \%$ of artisan household cash income. Improving the management of chambira palms requires the introduction of non-destructive harvest techniques and a wider use of the palm in agroforestry systems. An analysis of traditional management practices and of the role of chambira among Amerindian people indicates that A. chambira was an incipient domesticate at the time of the European conquest.
\end{abstract}

Keywords: Agroforestry, ethnic groups, fibers, handicraft, sustainable harvest

\section{Introduction}

Astrocaryum chambira (chambira or cumare) is one of the most important palm species for the indigenous communities of the northwestern Amazon as the fibers obtained from its unexpanded leaves are used to make a great variety of products for daily needs, such as hammocks, bags, or fishing nets (Jensen \& Balslev 1995; Vormisto 2002; Coomes 2004; Bernal et al. 2011; Mesa \& Galeano 2013). Its harvest and processing are a part of aboriginal traditions, and these activities represent important times for social interactions (Gallego 2005). In recent decades, chambira products have gained great acceptance among tourists and craft stores, and the palm has become an important cash crop for indigenous families. The frequent extraction, sometimes conducted destructively, has depleted natural populations in some places (Lema 2003; Coomes 2004; Castaño et al. 2007; Linares et al. 2008).

Although chambira fiber has long been popular in the Colombian Amazon, only in the last few years has it been introduced into the most important craft fairs in Bogotá (Linares et al. 2008). Its marketing has increased as Colombian people have come to know it and as tourism in the Amazon region has grown over the last few decades. However, knowledge about chambira management practices and their impact on natural populations has not grown accordingly. Only recently have ecological and ethnobotanical studies begun to consider the conservation status of populations, and alternatives to reduce the impact of its harvest (Lema 2003; Castaño et al. 2007). As a method of integrating that information, this paper presents a complete documentation of the traditional management of A. chambira in the Colombian Amazon; sustainable and non-sustainable aspects of its harvest are identified and critical guidelines are mentioned to guarantee a sustainable use. Data originated from three years of study in the Colombian Amazon among indigenous communities of Leticia, San Martín de Amacayacu, Nazareth, Puerto Nariño, Tarapacá, and La Chorrera. Additional data from other localities were recovered from the literature in order to provide a regional view.

\footnotetext{
${ }^{1}$ Departamento de Biología, Facultad de Ciencias, Pontificia Universidad Javeriana, Bogotá, Colombia.

${ }^{2}$ Instituto de Ciencias Naturales, Universidad Nacional de Colombia, Apartado 7495, Bogotá, Colombia.

${ }^{3}$ Instituto Amazónico de Investigaciones Científicas SINCHI, Bogotá, Colombia.

${ }^{4}$ Department of Biosciences, Aarhus University Build 1540, Ny Munkegade 114-116, 8000 Århus C, Denmark.

Author for correspondence: nestor.garcia@javeriana.edu.co
} 


\section{Materials and Methods}

\section{Study Species}

A. chambira Burret. is a solitary palm up to $27 \mathrm{~m}$ tall. Its stem, up to $30 \mathrm{~cm}$ in diameter, is armed with flattened, black spines up to $20 \mathrm{~cm}$ long, and is topped with a funnelshaped crown bearing 8-20 leaves up to $8 \mathrm{~m}$ long, with 110-135 leaflets per side (the most distal leaflet is wider than the others). The petioles in juvenile palms are covered with yellowish-gray, winged spines, up to $15 \mathrm{~cm}$ long. Male and female flowers are borne on the same inflorescence. Further, fruits are obovoid, yellowish green when ripe, up to $7 \mathrm{~cm}$ long, and 4-5 cm in diameter (Henderson et al. 1995; Galeano \& Bernal 2010). The palm grows in the western Amazon region, from Venezuela to Peru and western Brazil; in Colombia, it grows in wet lowlands, in terra firme, and in gallery forests at $100-500 \mathrm{~m}$ elevation. It is scarce in forests and is often planted or preserved in slash-and-burn plots (Galeano \& Bernal 2010).

\section{Study area}

The Colombian Amazon region extends from the Andes to the border with Venezuela and Brazil, and from the Guaviare River south to the border with Peru and Ecuador.
It comprises $483,160 \mathrm{~km}^{2} ; 5.76 \%$ of the whole Amazon basin and $42.3 \%$ of the continental area of Colombia (SINCHI 2012). Most of the area is covered by terra firme or temporarily or permanently flooded tropical rainforest. The annual deforestation rate is $0.01 \%-3.73 \%$ (Armenteras et al. 2006).

Although the Colombian Amazon has been occupied since ancient times by many Amerindian groups, today these groups represent only approximately $10 \%$ of the population (DANE 2005). The most recent figures indicate that there are 52 Amerindian groups in the Colombian Amazon, who live in collective territories and whose production systems are characterized by slash and burn agriculture (DANE 2007; Ruiz et al. 2007; Arcila 2011). Over the past few decades, the Amazon Amerindian groups have been subject to numerous territorial disputes, displacement, and introduction into the market economy (Dominguez 2005; Arcila 2011), probably affecting their traditions and the way they manage their resources.

\section{Methods}

We used semi-structured interviews and field observations to characterize chambira harvest, processing, and marketing. Between 2009 and 2012, we visited four communities and two marketing centers (Fig. 1) in the Amazon region. We visited only those communities for which a research

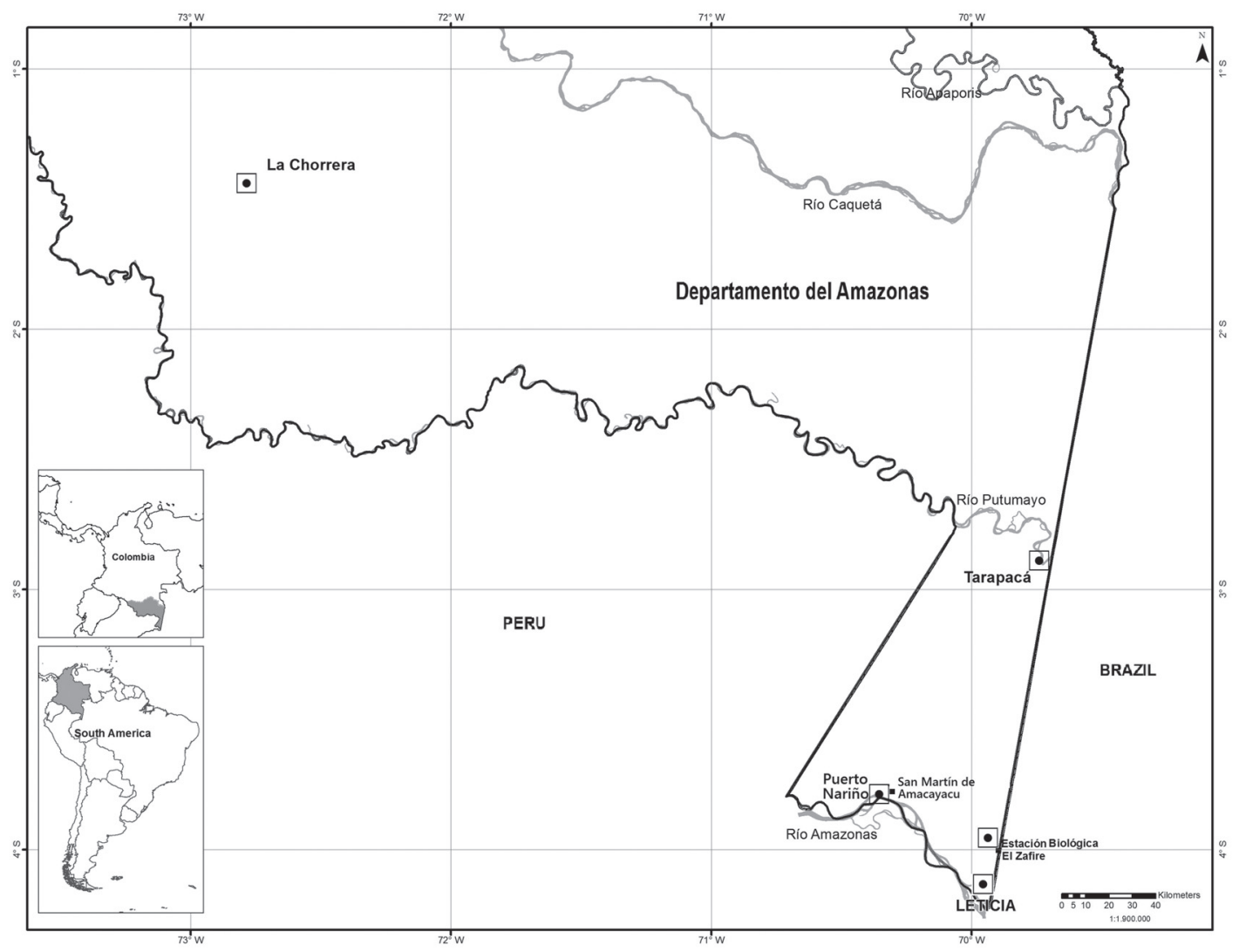

Figure 1. Colombian Amazon indicating locations of villages, towns, and rivers mentioned in the text. 
permit was obtained. Most observations were made at the Tikuna village of San Martín de Amacayacu, where a study of the demography of this palm was conducted (García 2013). This village has approximately 500 inhabitants, and only $25-30$ of them usually harvest and process chambira fibers. We interviewed people who voluntarily accepted to collaborate: five women and a man, all aged between 20 to 45 years old. At this community we made observations of fiber harvest and processing, which included measuring the size of harvestable palms, recording the duration of harvest and processing, counting the number of spear leaves harvested per workday, and quantifying fiber production per leaf. All these data were included in the description of chambira management. At the village of Nazareth, and at the markets of Leticia and Puerto Nariño, three voluntary indigenous women and three voluntary mestizo shop keepers were interviewed. We made additional observations on chambira harvest and processing at Tarapacá and La Chorrera. Our interviews included members of the Tikuna, Witoto, Ocaina, Bora, and Muinane indigenous groups. In order to broaden our scope of chambira management in the Amazon we reviewed several published and unpublished documents on various aspects of the subject (Goldman 1963; Wheeler 1970; Schultes 1977; Correa 1979; Balick 1979; Pabón 1982; Garzón 1985; Henao 1989; Galeano 1992; Hammond et al. 1995; Morcote-Rios et al. 1998; Antolinez 1999; Lema 2003; Cadena 2005; Sánchez et al. 2005; López et al. 2006; Cárdenas et al. 2007; Castaño et al. 2007; Linares et al. 2008; Frausin et al. 2010; Valderrama 2011; Marín et al. 2012; García 2013; Mesa \& Galeano 2013).

To assess the state of populations and the availability of the resource, we recorded palms at harvest places in seven $50 \mathrm{~m} \times 20 \mathrm{~m}$ plots, five of them in San Martín de Amacayacu and two at $\mathrm{km} 13$ on the Leticia-Tarapacá road. We incorporated the results from eleven $100 \mathrm{~m} \times 10 \mathrm{~m}$ transects made at Tarapacá and La Chorrera for a different purpose. We also sampled an unharvested population of A. chambira in the permanent 20 ha plot established at Estación Biológica El Zafire, near Leticia. The study areas were not chosen on the basis of any particular design but because research permits were obtainable for these areas. Because of this constraint, we made no statistical comparisons of the results. At each plot or transect, palms were classified according to their size as proposed by Galeano et al. (2010): seedlings (acaulescent with bifid leaves), juveniles (acaulescent with pinnate leaves), subadults (caulescent, non-reproductive individuals), and adults (reproductive individuals).

To determine the leaf production rate, 75 harvestable palms at San Martín de Amacayacu were followed during one year. We selected all acaulescent and stemmed individuals that local people considered as harvestable. On each palm, the youngest expanded leaf was marked, and the new leaves produced after one year were counted. Additionally, to get a better understanding of current management, we incorporated data on growth and age taken by García (2013) at San Martín de Amacayacu.

\section{Results}

The use of chambira fiber has been recorded among 21 aboriginal groups in the Colombian Amazon: Andoque, Awa, Coreguaje, Cubeo, Guayabero, Macuna, Miraña, Murui Muinane, Nonuya, Nukak, Ocaina, Piapoco, Sikuani, Siona, Taiwano, Tikuna, Tucano, Tuyuka, Witoto, Yagua and Yukuna (Wheeler 1970; Schultes 1977; Correa 1979; Pabón 1982; Garzón 1985; Galeano 1992; Morcote-Rios et al. 1998; Antolinez 1999; Cadena 2005; Gallego 2005; Sánchez et al. 2005; López et al. 2006; Cárdenas et al. 2007; Castaño et al. 2007; Frausin et al. 2010; Mesa \& Galeano 2013). At least 14 products are made from chambira fiber: threads, ropes, fishing nets, strainers, hammocks, traps, arrows and harpoons, bags, mats, baskets, clothes, garments, belts, bracelets (Mesa \& Galeano 2013). Additionally local communities use the seeds and the palm heart as food, and the endocarps as raw material for producing rings and bracelets, or as containers. The stems are occasionally used as building material or as a source of larvae of the palm weevil Rhynchophorus palmarum (Castaño et al. 2007). The leaflet midveins are used for making brooms, the leaflets as the source of a green dye, the fruit as medicine, and the stem as firewood.

\section{Harvest areas}

Harvested palms are found near human settlements (Fig. 2A and B), both in active crop plots and in old plots, fallows, and secondary forests (Henao 1989). The densities of A. chambira at several localities in the Colombian Amazon, including harvested populations surveyed in our study, are shown in Tab. 1.

Some of the lowest chambira densities occured in areas where the palm is not harvested, such as the mature forest of El Zafire or the old growth forests of Amacayacu. In slashand-burn plots and in fallows where chambira is harvested, it is considerably more abundant. The density of adults is particularly low at the first three localities listed in Tab. 1, which are close to Leticia and Puerto Nariño; this is where fiber harvest is intense and tall palms are often cut down.

Lema (2003) recorded few adult palms in Macedonia, a Tikuna village near Leticia, although figures were not provided. Lema considered the scarcity of adult palms to be a result of juvenile deaths caused by intensive leaf harvest. In Tarapacá, on the Putumayo River, where chambira is scarcely used today, adult density was almost twice that of harvested areas along the Amazon River, but similar to palm density at La Chorrera where harvest frequently occurs. On the Vaupés River, 32 productive palms per hectare were found by Cárdenas et al. (2007), although their size categories were not detailed.

Chambira management currently ranges from sparing individuals and favoring their development, to the total elimination of plants for harvest. A common practice near the Amazon River is to spare adult palms when practicing 


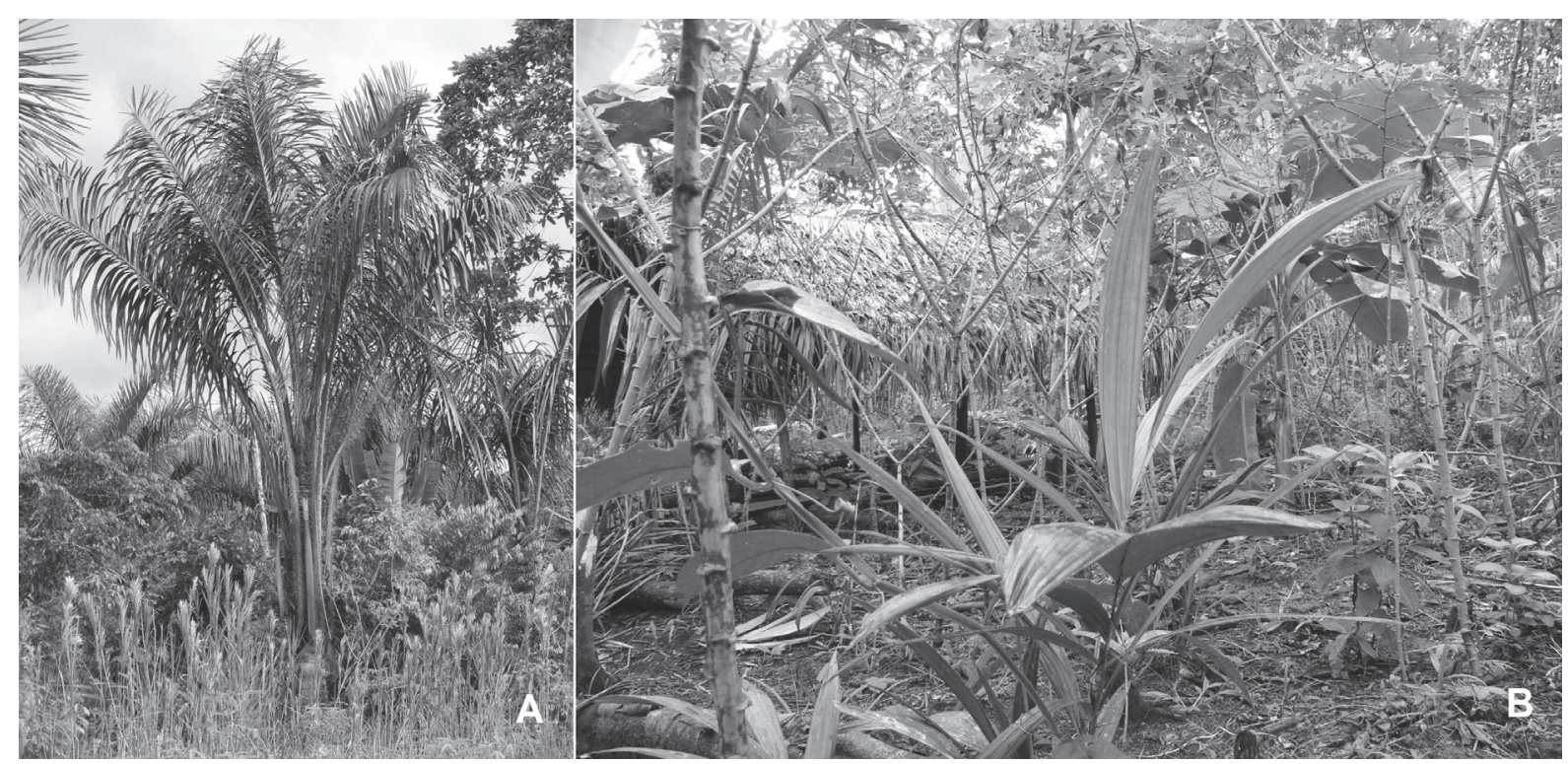

Figure 2. Astrocaryum chambira growing in Amazon homegardens, Colombia. A, Adult palm. B, Juvenile palm.

Table 1. Density of Astrocaryum chambira at several localities of the Colombia Amazon. Areas where the palm is not harvested are marked with *

\begin{tabular}{|c|c|c|c|c|c|}
\hline \multirow{2}{*}{ Locality } & \multicolumn{4}{|c|}{ Individuals ha $^{-1}$} & \multirow{2}{*}{ Total } \\
\hline & Seedlings & Juveniles & Subadults & Adults & \\
\hline San Martín de Amacayacu & 944 & 260 & 10 & 12 & 1226 \\
\hline km 13 road Leticia-Tarapacá & 160 & 390 & 15 & 10 & 575 \\
\hline Vicinity of Leticia (Castaño et al. 2007) & - & - & - & 17 & 878 \\
\hline Tarapacá & 270 & 190 & 20 & 30 & 510 \\
\hline La Chorrera (2-3 hr from village) & 14 & 87 & 41 & 27 & 168 \\
\hline La Chorrera (near village) & 16 & 98 & 18 & 26 & 158 \\
\hline PNN Amacayacu (Lema 2003)* & - & - & - & - & 52 \\
\hline Macedonia (Lema 2003) & - & - & - & - & 44 \\
\hline Estación Biológica El Zafire* & 10 & 13 & 0 & 1 & 24 \\
\hline
\end{tabular}

slash-and-burn agriculture; in other cases not only tall individuals are kept, but also acaulescent juveniles and seedlings; but in some other cases, palms are eliminated altogether. The Tikuna living along the Amazon claim that the ancestral use of transplanting seedlings into their forest plots is still practiced. Hammond et al. (1995) included chambira (as A. vulgare) to be among the plants in agricultural systems that are selectively managed by the Tikuna of Las Palmeras, near Leticia. Cultivation of this palm has been promoted in several Indian reservations in the Amazon basin and the eastern plains of Colombia, in order to increase availability of the fiber (Linares et al. 2008).

\section{Harvest of chambira}

Chambira harvest is mostly opportunistic (i.e., it is done in passing), while developing other activities such as working in forest crop plots, although specific harvesting journeys are sometimes undertaken if fiber is needed. Such harvest expeditions sometimes take several hours, as harvestable palms are scarce. Among the Tikuna, a chambira harvest is sometimes done by means of collective work (minga); a family can arrange up to two mingas per year, getting up to 35 spear leaves during each of them.

Fiber is obtained from the unexpanded leaves of the largest acaulescent or of the lowest stemmed palms (Fig. 3A). As seen in San Martín de Amacayacu, large acaulescent palms appropriate for harvest had 4-9 leaves, each with $78-116$ leaflets per side $(X=97.38, S D=11.38 ; n=16)$; it takes a palm 19 years to reach the minimum size required for harvest, then an increase in the number of leaflets in consecutive leaves, combined with the leaf production rate, results in a net increase of four leaflets per side per year, on average (García 2013). As the palm grows and develops a stem, access to the crown becomes more difficult. Because of this, only lower stemmed palms are harvested. These are 
usually palms with a stem up to $2.2 \mathrm{~m}$ tall, with 6-17 leaves $(\mathrm{X}=10.67, \mathrm{SD}=3.93, \mathrm{n}=6)$, mostly not yet reproductive.

Chambira palms start to develop an aerial stem when their leaves have 105 leaflets per side, on average; at this point they are approximately 28 years old. The stem grows $63.8 \mathrm{~cm}$ year $^{-1}$ on average, reaching the tallest height for non-destructive harvest $(2.2 \mathrm{~m})$ when the plant is approximately 32 years old. However, if a leaf urgently needed is found on a taller palm, where harvest is deemed more dangerous, the palm is just cut down. This has become a widespread practice throughout the northwestern Amazon basin (Lema 2003; López et al. 2006; Linares et al. 2008).

Unexpanded leaves are harvested by using a hook and a machete. Acaulescent palms are the easiest to harvest-the harvester hooks the spear leaf and bends it out of the crown, and then cuts it with the machete. For stemmed palms, several strategies are used: the most common one is to attach a machete to the end of a pole, and to cut the leaf from the ground; less often, a trunk is lent to the palm, and used as a ramp to reach the crown; in rare cases, a scaffold is built near the palm as a permanent platform. Some expanded leaves of the palm are often cut in the harvest process, in order to facilitate access to the spear leaf through the heavily spined petioles (Castaño et al. 2007).

Spear leaves are harvested when they are close to expanding, and measure 3.5-4 (-6) $\mathrm{m}$ long (pers. obs. at San Martín de Amacayacu; Lema 2003). Only one spear leaf is obtained from each palm. Harvesters identify the appropriate leaves based on their size and grayish-green color. After cutting the spear leaf, it is shaken and beaten with the machete to loosen the leaflets, which are then detached by hand. One leaf produces $150-200$ usable leaflets $90-150$ $\mathrm{cm}$ long and $18-25 \mathrm{~mm}$ wide. Basal and apical leaflets are not harvested, as they are shorter; among the Tikuna there is a belief that collecting these shorter leaflets may trigger disease to the harvester. A widespread use among the Tikuna and Witotos is to test fiber quality in situ. They extract some fiber from the just harvested spear leaf and test its resistance. If the fiber does not break, they take the leaflets; if it breaks, they just abandon the harvested leaf. Up to eight spear leaves can be easily harvested in half a day of work, although production depends on the abundance of palms. Spear leaf harvest has been poorly documented in other areas of the Amazon, but based on the reports of informants and on our casual observations, it is apparently similar. According to Wheeler (1970), the Siona of the upper Putumayo used a machete or an ax to open the palm crown and cut the spear leaf, but no information is provided on the size of palms harvested.

As chambira harvest is not an organized activity, and since it is mostly opportunistic, no information is available on harvest frequency. The palms in our plot in San Martín de Amacayacu showed evidence of 1-4 harvested leaves in acaulescent individuals, and 1-5 in stemmed plants; sometimes up to three consecutive leaves had been harvested.
Harvestable acaulescent palms at this site produce less than two leaves per year on average $(X=1.59, S D=0.81, n=43)$, and stemmed individuals produced approximately three leaves per year $(\mathrm{X}=2.89, \mathrm{SD}=0.44, \mathrm{n}=32)$. At the nearby community of Mocagua, Lema (2003) observed up to three consecutive leaves harvested per palm. Sometimes palms are intensively harvested to death, as seen by us in three juveniles in San Martín de Amacayacu, and as reported by Lema (2003) at Mocagua. Around San Martín de Amacayacu, at least 12 subadult and adult chambira palms were cut down during 2010-2012, a figure corresponding to approximately $13 \%$ of all palms found by us in these size categories at that place.

\section{Fiber processing}

Whereas fiber harvest is done by both men and women, fiber processing and artifact manufacture is strictly a women's activity (Fig. 3B-D). Processing is done at home, usually the day after harvest. If there are many leaflets, several women share the work. While sitting on the floor, they take the leaflet by its base and with their fingernail they separate the midvein in its basal $10-15 \mathrm{~cm}$. They then take one of the blade halves and bend it downwards 10-15 $\mathrm{cm}$ from the base. At the bending point the blade is firmly held between the thumb and index finger and the bent end is pulled strongly and quickly with the other hand to separate the outer (non-vascular fibers of the adaxial side, Marín et al. 2012) from the inner (vascular fibers). After this quick movement, both fiber types are rubbed with the thumb and index finger to separate them even more, and then the index finger is slipped between them, breaking the inner fibers, and leaving the outer fibers attached to the adaxial epidermis, and looking like a thin, translucent membrane. This membrane is then separated from the lamina, down to the base and partially towards the apex. The same procedure is done with the other leaflet half. At the end, the two translucent membranes (each made up of non-vascular fibers and adaxial epidermis) remain attached to the apex of the leaflet, which has the midvein partially loose. The leaflets are piled in this state.

When the process described above has been completed for all the leaflets, they are taken again one after the other and the fibrous membrane is completely loosened. To do this, one of the leaflet halves is taken by its base, the apex is pressed down with the foot, and the fiber is taken with the other hand and pulled toward apex with a quick movement, keeping it straight until it loosens completely. The same procedure is done with the other leaflet half, and the process is repeated until the fibers from several leaflets accumulate in the hand. After this, they are arranged by one of their ends and placed on the floor. Extracting the fiber from a whole spear leaf takes approximately one hour.

Once the fibers have been extracted, they are tied together by one end and hung out for one or two nights; this period is considered by some women as a part of the 


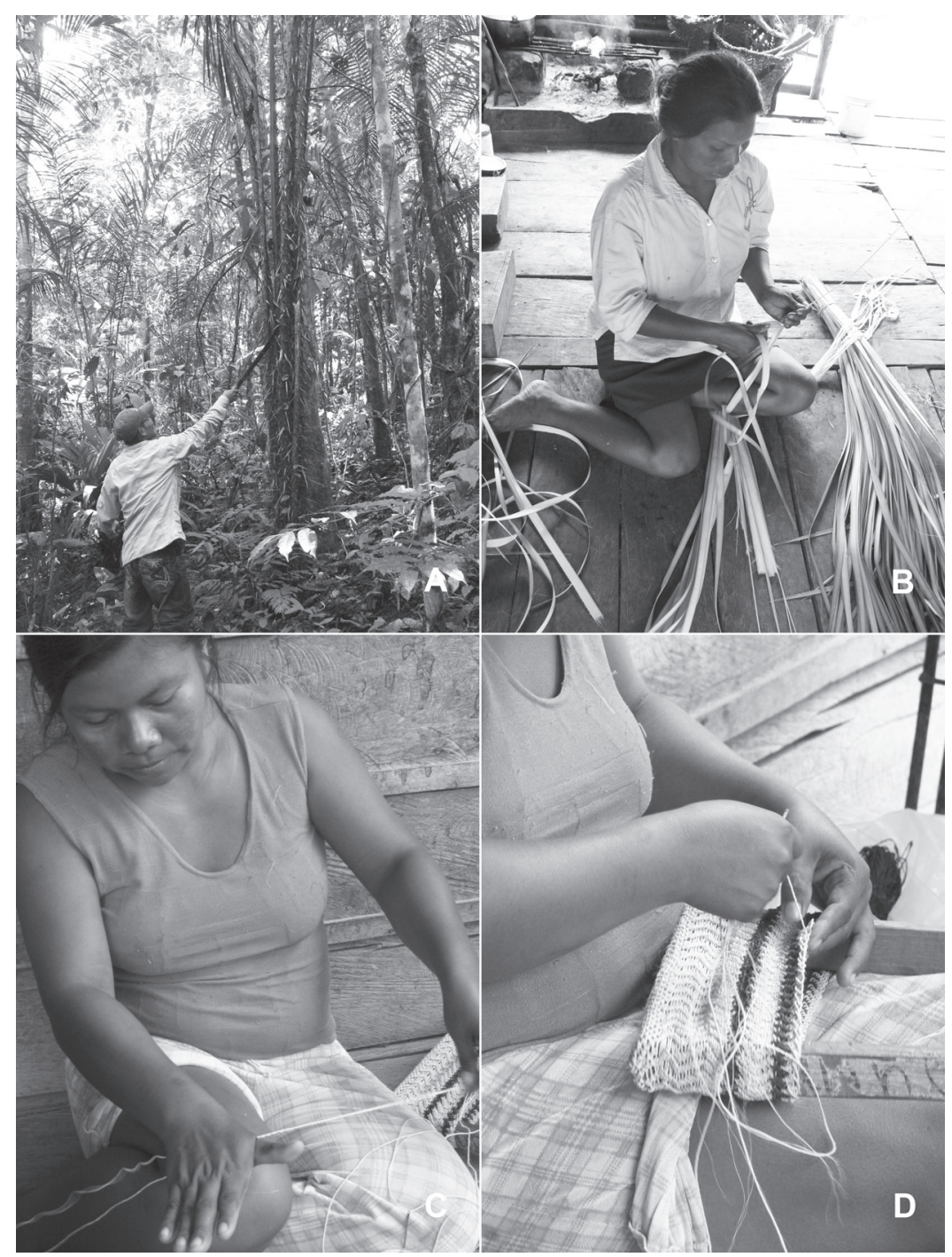

Figure 3. Harvesting and processing leaves of Astrocaryum chambira by Tikuna people. A, Harvesting spear leaves. B, Processing leaflets. C, Twisting. D, Weaving a bag.

required treatment. The fibers are then boiled for $10-20$ minutes, sometimes adding a few drops of lemon juice to improve bleaching. They are then washed with detergent, adding lemon juice again. They are then rinsed and hung out under the sun for one or two days. The final product is a raw, white fiber.

Chambira fiber is dyed with natural pigments, or occasionally with a mixture of natural pigments and commercial dyes. Several different plants are used for dying chambira fiber among the Colombian Tikuna of the Amazon River (Tab. 2). Dying is achieved by boiling the raw fiber or the twisted threads with the corresponding plants or dyes, sometimes adding lemon juice as mordant. The product is then rinsed and hung out to dry for several days. It is then stored until used.

The strings used for weaving are twisted by the women while sitting on the floor with stretched legs. They take a couple of fibers, match them, put the thinner ends between the first and second toes, and hold the other end with one hand; with the other hand they twist the fibers by rolling them over their thigh (Fig. 3C); the ends held between the toes are then loosened, disentangled, and pressed again between the toes for twisting a new portion of string; the same procedure is repeated three or four times, upon which new fibers are added; in this way, very long strings are produced, which are made into balls. Twisting is one of the most time-consuming works; 11-12 hours of work is required for twisting the strings required to weave a hand bag ( $240 \mathrm{~g})$.

The remaining portion of the leaflets are used for producing different items. The midveins are separated from the blades, dried under the sun, and used to make brooms. The remaining blades have been used in the last few years in some Amerindian communities along the Amazon River as the foundation rod for trays and low baskets produced using the single-rod coiled technique. 
Table 2. Plants used to dye Astrocaryum chambira fiber by the Colombian Tikuna along the Amazon River.

\begin{tabular}{lc}
\hline Plant & Color \\
\hline Huito (Genipa americana L. - Rubiaceae) & Several hues of blue \\
Achiote (Bixa orellana L. - Bixaceae) & Orange \\
Platanillo (Renealmia alpinia (Rottb.) Maas - Zingiberaceae) & Purple \\
Azafrán (Curcuma longa L. - Zingiberaceae) & Yellow \\
Palo Brasil (Simira cordifolia (Hook.f.) Steyerm. - Rubiaceae) & Red \\
Bejuco (Fridericia chica (Bonpl.) L.G.Lohmann - Bignoniaceae) & Red \\
Bijao (Calathea standleyi J.F.Macbr. - Marantaceae) & Blue (Lema 2003) \\
Chontaduro (Bactris gasipaes Kunth - Arecaceae) & Green \\
Palometa guayu (Neea virens Poepp. ex Heimerl - Nyctaginaceae) & Purple (Lema 2003) \\
\hline
\end{tabular}

\section{Product manufacture}

The most common technique for chambira product manufacture is macramé (Figs. 3D, 4A-B), with knots made manually. For producing hand bags, wooden casts are often used, around which the strings are woven; for a bracelet, a small wooden board is used, and the string is tied to a nail driven on it. Hammocks require a wooden frame; Siona men weave their hammocks by setting a wooden frame with two rods, one of them attached to the floor and the other one to the roof. Weaving is loosely done between both rods (Wheeler 1970).

A variety of artifacts are produced using chambira fiber, either exclusively or partially. The most common items marketed in the Colombian Amazon include hand bags, bracelets, hammocks, necklaces, placemats, hats, and trays (Fig. 4A-C). Other items were formerly used in everyday life but are now rarely found or have disappeared altogether. These included fishing nets, arch strings, harpoons, animal traps, basket handles, and ties for clothes and ceremonial ornaments. In ceremonial clothes, chambira fiber is indispensable even today; it is used twisted and woven into wrist or ankle bracelets and necklaces or raw for decorating clothes with fringes and tassels. The production of hammocks, the iconic chambira product of Ecuador and Peru (Jensen \& Balslev 1995; Vormisto 2002), is now scarce in the Colombian Amazon. According to local people, the large amount of fiber required and the labor-intensive weaving are not economically viable for market sales, particularly when they compete with the much cheaper, introduced cotton hammocks. Smaller bags and bracelets, which have a low price and are easily sold, are preferred by shop keepers.

On average, $150-180 \mathrm{~g}(\mathrm{X}=164, \mathrm{SD}=11.14, \mathrm{n}=5)$ of dry fiber are obtained from a leaf, and this amount produces $133-159 \mathrm{~m}$ of string $(1 \mathrm{~m}=1.13 \mathrm{~g})$. One or two leaves are required to produce a hand bag, and up to eight to produce a hammock (Tab. 3). Harvesting and processing one leaf to obtain the raw fiber requires approximately three hours of effective work, distributed over two or three days.
Besides traditional products, artisans from Leticia and Puerto Nariño have started to produce trays, bread baskets, and placemats (Fig. 4C) using the single-rod coiled technique. In this technique, a foundation or core, made out of the discarded leaflets after fiber extraction, is coiled, and successive coils are tied with stitches of chambira fiber. It is the same technique used by the Wounaan on the Pacific Coast of Colombia to weave the fiber of $A$. standleyanum (Bernal et al. 2013; García et al. 2013), although the quality of the Amazonian chambira products is not yet the same as those from the Wounan of the coastal plain. Processed chambira fiber, as well as products, can be stored for long periods, if kept in fresh, aerated places. Local shop keepers expose artifacts to sun from time to time.

\section{Marketing}

Marketing of chambira products as handicrafts, particularly bags and hammocks, was known as early as the 1960s and 1970s (Goldman 1963; Wheeler 1970; Schultes 1977; Balick 1979), but it increased in the 1980's, as tourism in the area grew, until reaching the wide diversity of items available today. Although chambira handicrafts are found throughout the Colombian Amazon region, the market for chambira products is centered at the towns of Leticia and Puerto Nariño, and at most indigenous villages along the Amazon River; these are the areas most visited by tourists (Castaño et al. 2007; Linares et al. 2008).

In the last few years, chambira handicrafts have been exhibited at Expoartesanías, Colombia's largest handicraft fair, held annually by December in Bogotá, where they have gained increasing popularity. Between 2005 and 2006, 27 chambira exhibitors took part in this fair, representing approximately 250 artisans. Most participants belonged to indigenous communities of Leticia and surrounding areas, and the departments of Vaupés and Vichada, and to a lesser extent the departments of Caquetá, Meta, Guaviare, and Guainía (Linares et al. 2008). Participation in handicraft fairs is regarded as an opportunity for increasing incomes. 


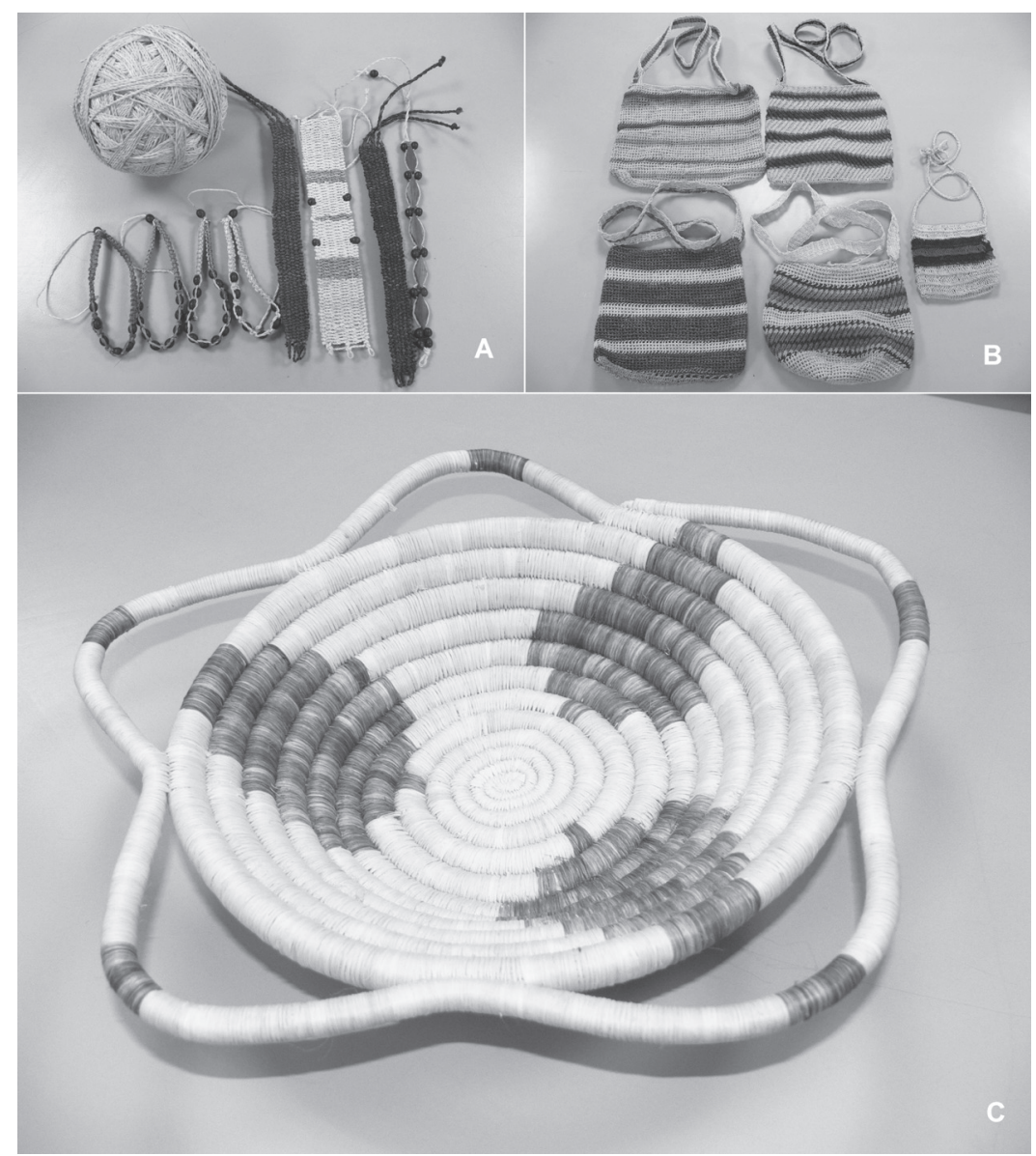

Figure 4. Handicrafts made with Astrocaryum chambira fibers. A, String and bracelets. B, Bags. C, Tray produced with the single-rod coil technique.

Table 3. Some products made by the Tikuna of the Colombian Amazon River using Astrocaryum chambira fiber. Time of manufacture includes only string twisting and product weaving.

\begin{tabular}{|c|c|c|c|c|}
\hline Product & Weight (g) & Number of leaves & Time of production (hr) & Price (USD) \\
\hline Small hand bag $(14 \times 16 \mathrm{~cm})$ & 60 & 0.3 & 8 & 6 \\
\hline $\begin{array}{l}\text { Medium-sized hand bag } \\
\qquad(26 \times 27 \mathrm{~cm})\end{array}$ & 190 & 1 & 25 & 14 \\
\hline $\begin{array}{l}\text { Large hand bag } \\
(31 \times 28 \mathrm{~cm})\end{array}$ & 300 & 2 & 30 & 17 \\
\hline $\begin{array}{l}\text { Large bracelet } \\
\text { (4 } \mathrm{cm} \text { wide })\end{array}$ & 13 & 0.08 & $3 / 4$ & 3 \\
\hline $\begin{array}{l}\text { Small bracelet } \\
(0.6 \mathrm{~cm} \text { wide })\end{array}$ & 2 & 0.01 & $1 / 6$ & 0.6 \\
\hline Hammock & 1300 & 8 & 160 & 51 \\
\hline
\end{tabular}

Because work with chambira fiber is combined with domestic and crop plot activities, estimations of the time employed in the whole process is an approximation. Although bracelets and hand bags take a shorter time to produce, up to 20 days would be required to weave a hammock, if this activity alone were carried out. Hence item price is not proportional to amount of fiber required or the time invested, and thus smaller items are more profitable (Tab. 3).
Revenues from chambira represent $40 \%-100 \%$ of all cash incomes of indigenous families involved in fiber harvesting and processing near Leticia and Puerto Nariño (Valderrama 2011). The highest income is obtained when products are sold directly to tourists at the indigenous villages, but tourist affluence at villages has decreased in the last years. When products are sold in shops in Leticia or Puerto Nariño, revenues decrease up to more than 50\% 
(Valderrama 2011). An uncommon market strategy is to establish agreements directly with traders in other areas of the country, which has been done in San Martín de Amacayacu. Another strategy used by artisans from the most remote villages, is to sell their products through families inhabiting more frequently visited villages, like Macedonia on the Amazon River. The chambira market chain in the Colombian Amazon is short, with few middlemen besides shop keepers, for which chambira items represent only $10 \%-30 \%$ of their sales (Valderrama 2011).

Because leaf harvest and processing are so labor-intensive, often as a result of palm scarcity, some indigenous or mestizo women buy balls of chambira string for weaving. In 2012, chambira string was sold for USD $4.5-5.6 \mathrm{~kg}^{-1}$ at the neighboring Peruvian town of Caballococha.

\section{Discussion}

Leaf production recorded in our study (2-3 leaves year $\left.{ }^{-1}\right)$ for large acaulescent and low stemmed chambira palms differs from previous records of 4-6 in Ecuador (Jensen \& Balslev 1995) and 3-6 in Peru (Vormisto 2002; Coomes 2004). The difference is probable because information in Ecuador and Peru was obtained from interviews with local people, and not by following palms over time, as we did. Our experience with various palm species in several areas of Colombia has revealed the inaccuracy of local informants' casual estimations of leaf production rates (García et al. 2011; García et al. 2013). Therefore, we recommend that our figures of leaf production should be used in any management plans throughout the range of Astrocaryum chambira. This figure is similar to that found for two other fiber producing species in the genus, A. standleyanum and A. malybo (García et al. 2011; García et al. 2013).

Harvesters in Colombia, Ecuador, and Peru claim that harvesting every second leaf allows the palm to recover (Jensen \& Balslev 1995; Coomes 2004; Lema 2003). Based on our own data, this is also our recommendation. This would mean 1 leaf/palm year ${ }^{-1}$ in acaulescent palms, and 1-2 leaves/palm year ${ }^{-1}$ in stemmed palms. In San Martín de Amacayacu we found a harvest intensity of 0.3-1.1 leaves/ palm year ${ }^{-1}$, which means that in some cases harvest is slightly above the recommended intensity. For stemmed palms, the current harvest rate at that site (when the palm is not cut down) is $0.3-1.3$, and falls within the recommended limit. In other areas along the Amazon River in Colombia and Peru, harvest intensity above the acceptable limit has led to the death of acaulescent palms (Lema 2003; Coomes 2004).

Cutting down taller palms to get the spear leaves is an obstacle for the sustainable management of chambira in the Amazon basin. Besides our own observations in Colombia, destructive harvesting has been recorded also in Ecuador (Cruz 2006) and Peru (Vormisto 2002). In contrast, Jensen \& Balslev (1995) recorded appropriate management of cham- bira by Wauorani and Quichua communities of Ecuador, who harvested every second leaf and spared tall palms as seed sources.

The malpractice of cutting down palms, combined with the increasing demand for chambira products, accounts for the widespread decline of chambira populations throughout the Colombian Amazon (Linares et al. 2008). Our own data revealed a scarcity of stemmed palms in areas of intense use near Leticia. Artisans claim that at some communities along the Amazon River there are no more productive palms, and people must buy fiber from neighboring areas in Colombia or Peru (Valderrama 2011).

\section{Future use and management of chambira}

Considering the scarcity of A. chambira in mature Amazonian forests and its close association with humans, the future survival of this species will depend on the importance given to its fiber and to the appropriate management of palm populations associated with humans. Thus, chambira will rely on conservation through use, as described by Coomes (2004) and Bernal et al. (2011).

Inclusion of chambira in agroforestry systems has been repeatedly recommended (Pedersen \& Balslev 1992; Jensen \& Balslev 1995; Vormisto 2002; Coomes 2004). Our study shows that chambira was already a component of agroforestry systems in the northwestern Amazon basin, where it is currently declining. Recovering traditional knowledge and using new management strategies will be necessary to achieve agroforestry systems that include chambira and other eroded resources as an alternative for rural development in Amazonia, as proposed by Miller \& Nair (2006). This step is still to be taken.

New management strategies include the introduction of appropriate tools for harvesting chambira. At the Pacific lowlands of Colombia, where spear leaves of A. standleyanum represent an important source of fiber for handicraft production, there is a successful case study where the introduction of the medialuna (Fig. 5A and B), an S-shaped blade sharpened on both concave edges, combined with an awareness campaign, drastically reduced palm felling, and allowed for the recovery of declining palm populations (Bernal et al. 2013; García et al. 2013).

Another management practice that should be introduced is to harvest the leaflets of acaulescent palms without cutting the spear leaf, as practiced by campesinos with the acaulescent $A$. malybo at the lower Magdalena River in northern Colombia. In this region, the spear leaf is bent with a hook, and only the central, usable leaflets are detached, leaving basal and apical leaflets on the rachis. The leaf continues to develop and usually survives (García et al. 2011).

Another step that should be considered is to select individuals for propagation with fewer or no spines on the 

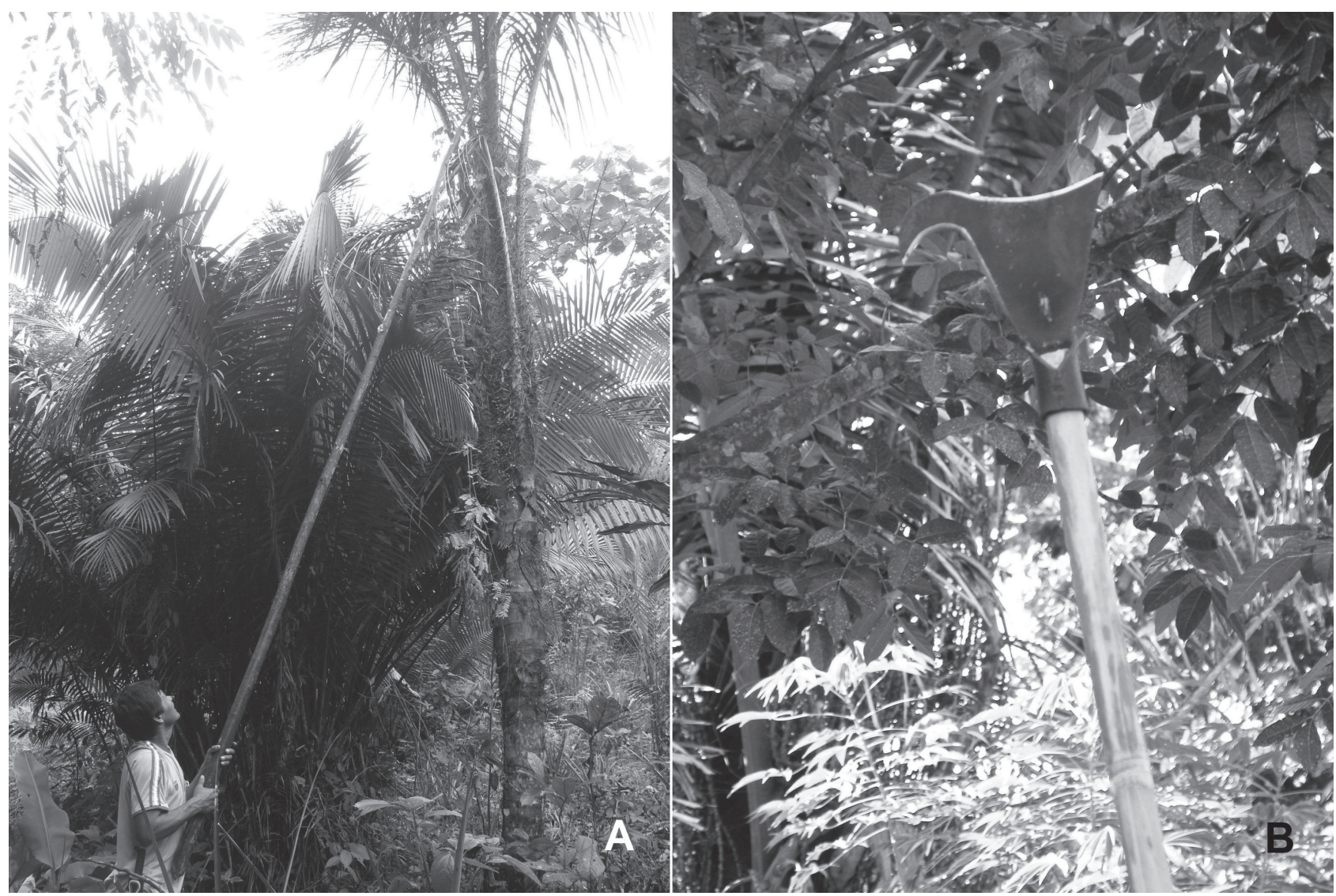

Figure 5. A, Tikuna man learning the use of the medialuna in Colombian Amazon. B, Detail of the medialuna.

stem, like those of the Ecuadorian Amazon at Yasuní National Park (R Bernal, unpubl. res.), which would facilitate management in crop plots. A comparison of fiber quality among palms with various spine qualities should be simultaneously undertaken. Considering the limited government support, genetic selection and cultivation initiatives could be conducted through participatory programs (Simons \& Leakey 2004), which directly focus on community needs, are based on traditional knowledge, encourage product transformation and increased value, and are conducted with limited resources.

Simultaneously, diversification of products and improvement of the market chain should be explored. Handicraft design workshops addressed to local communities as well as local handicraft fairs at Amazonian capital towns, as suggested by Castaño et al. (2007), would contribute to increased product value and a direct interaction of artisans with tourists and traders.

Throughout the northwestern Amazon, chambira is one of the few sources of local income for indigenous people (Jensen \& Balslev 1995; Vormisto 2002; Coomes 2004); therefore, it remains important despite unfair prices. The future of the craft will be linked to a regional developmental strategy focused on non-destructive harvest, enriched agroforestry systems, and better market chains.

\section{Chambira as an incipient domesticate}

Chambira grows in association with human communities, and it is mostly found in forest crop plots, old fallows, and secondary forests, whereas it is scarce or lacking in mature forests. At El Zafire biological station, for example, we found only one adult palm ha ${ }^{-1}$ in a 20 ha plot; and no single individual was found either in 16 transects $500 \mathrm{~m}$ $\times 5 \mathrm{~m}$ of mature forest along the Caquetá River or in 29 transects $500 \mathrm{~m} \times 5 \mathrm{~m}$ of mature forest along the Guaviare River (Balslev, unpubl. res.). In the Peruvian Amazon, Kahn (1988) found just one juvenile individual in 0.43 ha of terra firme forest on the Ucayali River, and Kahn \& Mejía (1991) found one individual in 0.71 ha in the same area. $\mathrm{H}$ Balslev (unpubl. res.) found only 0.04 individuals ha $\mathrm{ha}^{-1}$ in $132 \mathrm{ma}$ ture forest transects $500 \mathrm{~m} \times 5 \mathrm{~m}$ scattered in the Peruvian and Ecuadorian Amazon. Density in the mature forests of Yasuní, Ecuador, is three adult palm ha ${ }^{-1}$ (Cruz 2006). This panorama of scarce wild plants versus more abundant plants associated to humans is reminiscent of the one described for populations of the Brazil nut tree (Bertholletia excelsa), to which Clement et al. (2010) attributes humans as the primary dispersal agents. 
The use of chambira by Amazonian groups is obviously ancient. Morcote-Rios \& Sicard (2012) found chambira leaf phytoliths at a terra preta archeological site north of Leticia, dating back to 1230 years BP. Along the Caquetá River, chambira phytoliths have been found associated to huntergatherers dating back to 9750 years BP, and to agricultural groups 7440 years BP (G Morcote-Rios et al. unpubl. res.), whereas carbonized seed fragments date back to 9250 years BP (Morcote-Rios \& Bernal 2001).

The chambira palm is also deeply rooted in Amerindian myths and traditions (Nimuendaju 1952; Gallego 2005). Among the Yagua, the whole process of chambira fiber extraction is linked to the origin myth of their people, and nubile girls used to be isolated for a period of time for their ritual of passing, which they would spend twisting chambira fiber. Although they are no longer isolated today, young girls still devote part of their time to fiber twisting. Harvest is made by couples, and processing makes up a social event (Gallego 2005). Among the Siona of the upper Putumayo, menstruating women spent their time twisting chambira fiber, and this activity was considered a pastime for both men and women (Wheeler 1970).

By the mid- $19^{\text {th }}$ century, along the Amazon and the Rio Negro, Wallace (1853, as A. vulgare) found chambira to be $\because$ of great importance to the Indians, and in places where it is not indigenous, is cultivated with care in their mandioca fields and about their houses, along with the pupunha and other fruit trees." Agroforestry systems like those found by Wallace were well developed in the Amazon by the time of European contact (Roosevelt 1994; Clement 1999; Piperno \& Pearsall 1998; Piperno 2011; Miller \& Nair 2006), and comprised at least 138 crops, $68 \%$ of which were arboreal or perennial plants (Clements et al. 2010). It is easy to imagine that such an important raw material as the strong and flexible chambira fiber, hardly comparable to any other one available in the area, would have been an early introduction by Amazonian cultures into these systems. The ancestral and still surviving Tikuna practice of transplanting chambira seedlings to their crop plots is evidence of this. Such a practice, combined with the use of testing fiber quality in situ and discarding poor quality spear leaves, obviously leads to a selection for better-quality fiber. It would make no sense to admit that the same harvester, who discards a leaf because of its poor fiber quality, would transplant to his plot seedlings found growing under it. Thus, the combination of both practices would inevitably result in better fiber palms being associated to crops.

Management practices like these inevitably select individuals with favorable features, particularly when management has been practiced for a long time (Casas et al. 2007). Such plants, propagated and managed by people, but not necessarily dependent on them for completing their life cycle, are considered as incipient domesticates (Neto et al. 2014). As a consequence of management, they can have low phenotypic and genetic differentiation compared with their wild relatives (Casas et al. 2007; Neto et al. 2014), although their average phenotype is still within the range normally found in wild populations (Clement 1999). Under these considerations, chambira can be considered as an incipient domesticate. However, Neto et al. (2014) warn of the need for other indicators before making conclusions about the degree of domestication. Specific studies on phenotypic and genetic variation in wild and managed chambira populations are required, in order to have a deeper understanding of any past domestication of this palm.

Whatever its degree of domestication, it is clear that the use of the chambira palm and its importance to aboriginal people has decreased in the last centuries, as European contact has progressively led to a change in daily habits or to fiber replacement by synthetic materials. Hunting weapons, including arches and arrows built with chambira strings, were replaced by firearms; more recently, nylon substituted chambira in fishing activities, cotton replaced it in hammocks, and plastic strings took its place as tying material. Current use of chambira is associated to market economy rather than to subsistence, as it originally was. Past uses, particularly those related to fishing and hunting, are seldom found in present day Amazon. Hammocks, a vital implement for Amazonian groups in the past, are now rarely produced. Among the Brazilian Tikuna, the traditional chambira hammocks were already a declining tradition as early as 1920, and by 1949 they were produced only for sale to colonists (Nimuendaju 1952).

Today's chambira is still included in agroforestry systems but is becoming steadily scarcer, is destructively managed, is used mostly for market economy, and appears to be the declining remains of an incipiently domesticated plant that was displaced by new technologies. This is one more example of the erosion of Amerindian agroforestry systems after the European conquest.

\section{Acknowledgments}

We thank the inhabitants of San Martín de Amacayacu, Tarapacá, and La Chorrera for sharing their knowledge on chambira management; María Cristina Peñuela, Estación Biológica El Zafire (Universidad Nacional de Colombia, sede Amazonia) for sharing her data on palms; Gaspar MorcoteRios for sharing data of his archeological sites, and pointing out relevant references; Isabel Guzmán for helping us to produce the map. Fieldwork was conducted under the following project: Palm Harvest Impacts in Tropical Forest-PALMS (FP7-ENB-2007-1; contract from the European Commission no. 212631), Estudios Ecológicos para el Manejo sostenible de Palmas Útiles Colombianas-COLCIENCIAS (grant No. 110148925263), and Evaluación del efecto de la cosecha de Astrocaryum standleyanum y Astrocaryum chambira para la obtención de fibras en Colombia y propuestas de manejo para su uso sostenible-División de Investigación de la sede Bogotá de la Universidad Nacional de Colombia. 


\section{References}

Antolinez LD. 1999. La alimentación en la Amazonía: Estudio de caso entre los Coreguajes. PhD Thesis, Universidad Nacional de Colombia, Colombia.

Arcila OH. 2011. La Amazonia colombiana urbanizada: Un análisis de sus asentamientos humanos. Bogotá, Instituto Amazónico de Investigaciones Científicas - SINCHI.

Armenteras D, Rudas G, Rodriguez N, Sua S, Romero M. 2006. Patterns and causes of deforestation in the Colombian Amazon. Ecological Indicators 6: 353-368.

Balick MJ. 1979. Economic Botany of the Guahibo. I. Palmae. Economic Botany 33: 361-376.

Bernal R, Torres C, García N, et al. 2011. Palm management in South America. The Botanical Review 77: 607-646.

Bernal R, Galeano G, García N, Palacios A, Ceballos J. 2013. Botswanan palm basketry among the Wounaan of western Colombia: lessons from an intercontinental cultural exchange. Tropical Conservation Science Journal 6: 221-229.

Cadena CE. 2005. Plantas útiles para la elaboración de artesanías de la comunidad indígena Monifue Amena (Amazonas-Colombia). Monograph, Pontificia Universidad Javeriana, Colombia.

Cárdenas D, García JC, Vanegas JA, Jiménez DA, Vargas O, Gómez L. 2007. Plantas útiles y promisorias en la Comunidad de Wacuraba (Caño Cuduyarí) en el departamento de Vaupés (Amazonía colombiana). Bogotá, Instituto Amazónico de Investigaciones Científicas - SINCHI.

Casas A, Otero-Arnaiz A, Pérez-Negrón E, Valiente-Banuet A. 2007. In situ management and domestication of plants in Mesoamerica. Annals of Botany 100: 1101-1115.

Castaño N, Cárdenas D, Otavo E. (eds.). 2007. Ecología, aprovechamiento y manejo de sostenible de nueve especies de plantas del departamento del Amazonas, generadoras de productos maderables y no maderables. Bogotá, Instituto Amazónico de Investigaciones Científicas - SINCHI and Corporación para el Desarrollo Sostenibles del sur de la Amazonia - CORPOAMAZONIA.

Clement CR. 1999. 1492 and the loss of amazonian crop genetic resources. I. The relation between domestication and human population decline. Economic Botany 53: 188-202.

Clement CR, Cristo-Araújo M, Eeckenbrugge GC, Pereira AA, PicançoRodrigues D. 2010. Origin and domestication of Native Amazonian crops. Diversity 2: 72-106.

Coomes OT. 2004. Rain forest "conservation-through-use"? Chambira palm fibre extraction and handicraft production in a land-constrained community, Peruvian Amazon. Biodiversity and Conservation 13: 351-360.

Correa F. 1979. Condiciones materiales en la producción y reproducción social como fundamento de la dinámica histórica de los "Taiwano": Una comunidad Indígena del Noroeste Amazónico. Departamento de Antropología, Facultad de Ciencias Humanas, Universidad Nacional de Colombia. Bogotá.

Cruz D. 2006. Estudio ecológico de la palma Astrocaryum chambira para su manejo sostenible y evaluación socioeconómica de la extracción de su fibra, en dos comunidades Waorani del Parque Nacional Yasuní. Monograph, Pontificia Universidad Católica de Ecuador, Ecuador.

DANE - Departamento Administrativo Nacional de Estadísticas. 2005. Censo General 2005, República de Colombia. Dirección de Censos y Demografía, Bogotá.

DANE - Departamento Administrativo Nacional de Estadísticas. 2007. Colombia una nación multicultural: su diversidad étnica. Dirección de Censos y Demografía, Bogotá.

Domínguez C. 2005. Amazonía colombiana: economía y poblamiento. Bogotá, Universidad Externado de Colombia.

Frausin G, Trujillo E, Correa M, González V. 2010. Plantas útiles en una comunidad indígena Murui-Muinane desplazada a la ciudad de Florencia (Caquetá-Colombia). Mundo Amazónico 1: 267-278.

Galeano G. 1992. Las palmas de la región de Araracuara. Bogotá, Tropenbos-Colombia.

Galeano G, Bernal R. 2010. Palmas de Colombia-Guía de Campo. Bogotá, Universidad Nacional de Colombia.
Galeano G, Bernal R, Isaza C, et al. 2010. Protocolo para evaluar la sostenibilidad del manejo de palmas. Ecología en Bolivia 45: 85-101.

Gallego LM. 2005. El tejido en chambira, una actividad que une más que sogas. Boletín de Antropología 19: 164-185.

García N. 2013. Evaluación del efecto de la cosecha de Astrocaryum standleyanum y Astrocaryum chambira para la obtención de fibras en Colombia y propuestas de manejo para su uso sostenible $\mathrm{PhD}$ Thesis, Universidad Nacional de Colombia. Colombia.

García N, Torres MC, Bernal R, Galeano G, Valderrama N, Barrera VA. 2011. Management of the spiny palm Astrocaryum malybo in Colombia for the production of mats. Palms 55: 190-199.

García N, Galeano G, Bernal R, Balslev H. 2013. Management of Astrocaryum standleyanum (Arecaceae) for handicraft production in Colombia. Ethnobotany Research and Applications 11: 85-101.

Garzón NC. 1985. Aproximación etnobotánica en la comunidad Guayabero de Barrancón, Guaviare. PhD Thesis, Universidad Nacional de Colombia. Colombia.

Goldman I. 1963. The Cubeo: Indians of the Northwest Amazon. 2nd edn. Urbana, The University of Illinois Press.

Hammond DS, Dolman PM, Watkinson R. 1995. Modern Ticuna swiddenfallow management in the Colombian Amazon: Ecologically Integrating Market strategies and subsistence-driven economies? Human Ecology 23: 335-356.

Henao CI. 1989. Interpretación etnobotánica del mito del "Árbol de las frutas" en la tradición oral Huitoto como modelo de domesticación de las plantas en la Chorrera (Amazonas). Monograph, Pontificia Universidad Javeriana, Colombia.

Henderson A, Galeano G, Bernal R. 1995. Field guide to the Palms of the Americas. Princeton, Princeton University Press.

Jensen OH, Balslev H. 1995. Ethnobotany of the Fiber Palm Astrocaryum chambira (Arecaceae) in Amazonian Ecuador. Economic Botany 49: 309-319.

Kahn F, Mejia K. 1991. The palm communities of two "terra firme" forest in Peruvian Amazonia. Principes 35: 22-26.

Kahn F. 1988. Ecology of economically important palms in Peruvian Amazonia. Advances in Economic Botany 6: 42-49.

Lema C. 2003. Estudio comparativo de la estructura poblacional y densidad en poblaciones naturales de Astrocaryum chambira Burret sometidas a diferentes intensidades de extracción en el Parque Nacional Amacayacu (Amazonia colombiana). Monograph, Universidad de Antioquia, Colombia.

Linares EL, Galeano G, García N, Figueroa Y. 2008. Fibras vegetales usadas en artesanías en Colombia. Bogotá, Artesanías de Colombia S.A. Instituto de Ciencias Naturales.

López R, Navarro J, Montero M, Amaya K, Rodríguez M, Polania A. 2006. Manual de identificación de especies no maderables del corregimiento de Tarapacá, Colombia. Bogotá, Instituto de Investigaciones Científicas SINCHI and Cooperación Técnica Alemana - GTZ.

Marín M, Millán B, Kahn F. 2012. Anatomy and physicochemical properties of the chambira fiber. Revista Peruana de Biología 19: 3-10.

Mesa L, Galeano G. 2013. Uso de las palmas en la Amazonia colombiana. Caldasia 35: 351-369.

Miller RP, Nair PKR. 2006. Indigenous agroforestry systems in Amazonia: from prehistory to today. Agroforestry Systems 66: 151-164.

Morcote-Rios G, Cabrera-Becerra G, Mahecha-Rubio D, Franky-Calvo CE, Cavalier I. 1998. Las palmas entre los grupos cazadores recolectores de la Amazonía Colombiana. Caldasia 20: 57-74.

Morcote-Rios G. Bernal R. 2001. Remains of palms (Palmae) at archaeological sites in the New World -A review. The Botanical Review 67: 309-350.

Morcote-Rios G, Sicard TL. 2012. Las tierras pretas del Igarapé Takana: un sistema de cultivo precolombino en Leticia-Amazonas, Colombia. Bogotá, Universidad Nacional de Colombia.

Neto EMFL, Peroni N, Casas A, et al. 2014. Brazilian and Mexican experiences in the study of incipient domestication. Journal of Ethnobiology and Ethnomedicine 10:33.

Nimuendaju C. 1952. The Tukuna. University of California Publications in American Archaeology and Ethnology Vol. 45. Berkley and Los Angeles, University of California Press. 
Pabón EMA. 1982. Botánica Económica de la Amazonia Colombiana. Colombia Amazónica 1: 9-30.

Pedersen HB, Balslev H. 1992. Palmas útiles. Especies para agroforestería y extractivismo. Quito, Ediciones Abya-Yala.

Piperno DR, Pearsall DM. 1998. The Origins of Agriculture in the Lowland Neotropics. San Diego, Academic Press.

Piperno DR. 2011. The origins of plant cultivation and domestication in the New World Tropics. Current Anthropology 52: 453-470.

Roosevelt AC. 1994. Amazonian anthropology: Strategy for a new synthesis. In: Roosevelt AC. (ed.) Amazonian Indians from Prehistory to Present: Anthropological Perspective. Tucson, University of Arizona Press. p. 1-29.

Ruiz SL, Sánchez E, Tabares E, et al. 2007. Diversidad biológica y cultural del sur de la Amazonia colombiana - Diagnóstico. Bogotá, Corporación para el Desarrollo Sostenibles del sur de la Amazonia - CORPOAMAZONIA, Instituto Alexander von Humboldt - IAvH, Instituto Amazónico de Investigaciones Científicas - SINCHI, Unidad Administrativa Especial del Sistema de Parques Nacionales Naturales - UAESPNN and Bogotá D.C.
Sánchez M, Duivenvoorden JF, Duque A, Miraña P, Cavelier J. 2005. A stembased ethnobotanical quantification of potential rain forest use by Mirañas in NW Amazonia. Ethnobotany Research \& Applications 3: 215-229.

Schultes E. 1977. Promising structural fiber palm of the Colombian Amazon. Principes 21: 72-82.

Simons AJ, Leakey RRB. 2004. Tree domestication in tropical forest. Agroforestry Systems 61: 167-181.

SINCHI. 2012. La Amazonia. http://www.sinchi.org.co/index. php?option $=$ com_content $\&$ view $=$ article\&id $=665 \% 3$ Aregiones - de la-amazonia-colombiana\&catid $=48 \% 3$ Aregiones-de-la-amazoniacolombiana\&Itemid $=2691$.

Valderrama N. 2011. Value chain investigations of four Colombian palm species. MSc Thesis, Technische Universität München, Germany.

Vormisto J. 2002. Making and marketing chambira hammocks and bags in the village of Brillo Nuevo, Northeastern Peru. Economic Botany 56: $27-40$.

Wallace AR. 1853. Palm trees of the Amazon and their uses. London. J. VanVoorst.

Wheeler MA. 1970. Siona use of chambira palm fiber. Economic Botany 24: $180-181$ 